\title{
Lovastatin production using Pleurotus ostreatus and its medicinal properties analysis by docking
}

\author{
D. Lakshmanan and K.V. Radha* \\ Department of chemical Engineering, A C College of Technology, Anna University, Chennai - 600025 Tamilnadu, India
}

Accepted 4 June, 2013

\begin{abstract}
Lovastatin is an anti-lipidemic drug produced by various filamentous fungi as a secondary metabolite. In our study, Pleurotus ostreatus was used in the production of lovastatin by solid state fermentation process. $P$. ostreatus was grown on different substrate (wheat bran, rice bran, rice straw, sugarcane bagasse), from which the maximum yield was obtained when wheat bran was used as a substrate in solid substrate fermentation. Further, wheat bran was used as a substrate and was grown on different temperatures $\left(25,28,32\right.$ and $\left.35^{\circ} \mathrm{C}\right)$, in which a maximum yield was obtained at $28^{\circ} \mathrm{C}$. To determine its anti-lipidemic property and other medicinal properties like anti cancer, Alzheimer's disease a docking study was done using Auto dock Vina, in which various proteins responsible for the disease are targeted and studied. The docking studies prove that lovastatin can effectively help in the treatment of various diseases by effectively binding to various proteins which are responsible for cancer, apoptosis and Alzheimer's.
\end{abstract}

Key words: Lovastatin, fermentation, wheat bran, hydroxymethylglutaryl CoA reductases, Alzheimer disease.

\section{INTRODUCTION}

Lovastatin is a first known drug in statin family which was discovered in 1970s (Endo, 1976). It was initially produced from Aspergillus terrus (Endo, 1976). Various other organisms like Pleurotus ostreatus (Samiee et al., 2003), a marine actinomycetes (Srinu et al., 2010), Aspergillus parasiticus, Accremonium chrysogenum (Endo, 1992), Monascus pirpureus (Danuri, 2008) also has the ability to produce lovastatin. Lovastatin has many medicinal properties; therapeutically used as an antilipidemic for the reduction of cholesterol. The blood cholesterol level reduced by inhibiting the HMG- Co A reductase enzyme (Tobert, 1987), is an important enzyme in formation of cholesterol from acetyl Co A. Various other statin drugs were synthesized from lovastatin by semi-synthetic process. A huge study is being done for the production of lovastatin through solid state fermentation process as a low cost substrates like wheat bran, rice straw can be used, and also the water and power consumption are very less when compared with submerged fermentation process (Rajput and Raj, 2009). The quantity of lovastatin produced from the fermentation can be quantified by microbial assay using Candida albicans as lovastatin has an inhibitory effects on the mycelium fungus, which is based on the anti fungal property (Kumar et al. 2000). Long term use of lovastatin has shown to exhibit anti-cancer properties in human and also have shown to cure Alzheimer's disease in rats (Eckert et al, 2005). Even though many plants such as Zanthoxylum armatum, Origanum majorana L., Peganum harmala $\mathrm{L}$, and Salvia officinalis $\mathrm{L}$ are known to show a wide range of medicinal properties, a huge study need to be done to find its exact mechanism of action and also needs more formulation to be used as a medicine (Barakat et al., (2013); Steenkamp et al., 2013 Samy et al., 2013). Lovastatin can be used as a drug for various diseases by studying its mechanism of action with various proteins responsible for inducing of disease. A docking study was done with various proteins, 
interacting with lovastatin to know its binding over other proteins and to find its mechanism of action against various diseases. Glycogen synthase kinase- $3 \beta$, thymedylate synthase, TGF- $\beta$ receptor type I, focal adhesion kinase 1 , dihydrofolate reductase are few proteins which were targeted using chemotherapy to cure cancer in humans. Other proteins such as caspase-3, cyclindependent protein kinase-2, cyclin-dependent protein kinase-5, cyclin-dependent protein kinase-7, cyclindependent protein kinase-9, known as apoptosis protein, whose malfunction may lead to cancer, were also targeted.

In our study, various solid substrates (wheat bran, rice bran, rice straw and sugarcane bagasse) were screened to find the maximum yield and optimized temperature of lovastatin. Also, its medicinal properties were studied on various cancer and apoptosis proteins. Proteins responsible for Alzheimer's were taken and the docking study was done with lovastatin to know the effectiveness of the drug.

\section{MATERIALS AND METHODS}

\section{Materials}

All chemicals were of analytical grade obtained from Central drug house (CDH), Chennai, India including potato dextrose agar (PDA), $\mathrm{MgSO}_{4} .7 \mathrm{H} 2 \mathrm{O},\left(\mathrm{NH}_{4}\right)_{2} \mathrm{HPO}_{4}, \mathrm{NaCl}$. Various agricultural wastes such as wheat bran, rice bran, rice straw, sugarcane bagasse, oats meal, coconut shells, saw dust, corn, soya bean, chickpea shells were purchased from local market of Tamil Nadu, India. Lovastatin tablets was purchased from pharmacy in Chennai, Tamil Nadu, India and used as standard.

\section{Microorganisms}

The fungus, $P$. ostreatus was obtained from University of Madras, Chennai, Tamil Nadu. The stock cultures were maintained in PDA at $4^{\circ} \mathrm{C}$ and were subcultured for every 15 days with PDA. The sub cultures were grown in potato dextrose broth for 4 days and used as inoculum in solid state fermentation.

\section{Screening of different substrates for lovastatin production}

$P$. ostreatus was grown on different solid substrates (wheat bran, rice bran, rice straw, sugarcane bagasse). $10 \mathrm{~g}$ of each solid substrates was taken separately in Petri plates and was moistened with distilled water and steam sterilized at $121^{\circ} \mathrm{C}$ for $15 \mathrm{~min}$. The medium was cooled and inoculated with a four day old $P$. ostreatus culture. The culture flasks were then maintained at $25^{\circ} \mathrm{C}$ for 8 days. Further, the lovastatin was screened using $C$. albicans.

\section{Temperature optimization on lovastatin production}

A solid state fermentation was carried out using wheat bran as a solid substrate, where $5 \mathrm{~g}$ of the substrate was moistened with distilled water containing $\mathrm{MgSO}_{4} .7 \mathrm{H}_{2} \mathrm{O}(0.15 \mathrm{~g} / \mathrm{l}), \quad\left(\mathrm{NH}_{4}\right)_{2} \mathrm{HPO}_{4}$ $(0.25 \mathrm{~g} / \mathrm{l}), \mathrm{NaCl}(1 \mathrm{~g} / \mathrm{l})$ and steam sterilized at $121^{\circ} \mathrm{C}$ for $15 \mathrm{~min}$. They were inoculated with $P$. ostreatus and maintained at different temperatures $\left(25,28,32,35\right.$ and $\left.40^{\circ} \mathrm{C}\right)$, the culture was extracted on day seven and quantified. The experiments were conducted on duplicates and the analyses were performed in triplicates. The data were statistically analyzed and standard error bars were obtained.

\section{Extraction of lovastatin}

$P$. ostreatus was incubated for eight days at $28^{\circ} \mathrm{C}$. Later, plates were taken and dried at $60^{\circ} \mathrm{C}$ in hot air oven. From the dried culture, $1 \mathrm{~g}$ of the culture was taken in a test tube, to which $10 \mathrm{ml}$ of ethylacetate was added. This was vortexed for $15 \mathrm{~min}$ and stored at cold condition for $1 \mathrm{~h}$, centrifuged at $3000 \mathrm{~g}$ for $15 \mathrm{~min}$ for layer separation. The supernatant was collected and bioassay was carried at using $C$. albicans to find the concentration of lovastatin present in the culture extract as explained below.

\section{Bioassay with Candida albicans}

C. albicans was grown on PDA for $12 \mathrm{~h}$ at $28^{\circ} \mathrm{C}$. C. albicans was subcultured on fresh PDA plates at a concentration of $7 \times 10^{3}$ cells $/ \mathrm{ml}$ and grown at $28^{\circ} \mathrm{C}$. Fifty micro liters of the extracts were taken and transferred to $6 \mathrm{~mm}$ paper disk and placed on $90 \mathrm{~mm}$ petri plate containing $C$. albicans. The spacing between the control and the lovastatin were adjusted to be $15 \mathrm{~mm}$. Positive and negative controls were prepared by impregnating the paper with 50 $\mu \mathrm{l}$ of known concentration of lovastatin standard and ethylacetate, respectively. The plates were incubated for $12 \mathrm{~h}$ and zone of inhibition was recorded. A large diameter of the inhibition zone indicated a high titre of lovastatin (Vilches Ferrón et al., 2005).

\section{Docking of lovastatin using protein molecules}

Autodock was carried out for lovastatin drug to study the various medicinal properties. Autodock vina version 1.1.2, 2012. (Trott and Olson 2010) was used for the docking of lovastatin with various protein molecules. They were visualized using Molegro molecular (René Thomsen and Mikael H. Christensen, 2006.) viewer tool.

\section{RESULTS}

\section{Screening of solid substrates for lovastatin production}

Different solid substrates (wheat bran, rice bran, rice straw, sugarcane bagasse) were used to grow $P$. ostreatus to find the best solid substrate for maximum yield of lovastatin. Table 1 shows the results obtained for various substrates.

\section{Effect of temperature on production of lovastatin}

Various temperatures $\left(25,28,32\right.$ and $\left.35^{\circ} \mathrm{C}\right)$ was maintained in $P$. ostreatus culture and their effect on lovastatin was determined on day seven. Figure 1 shows the yield of lovastatin on various temperatures.

\section{Study of various medicinal properties of lovastatin using autodock vina}

Lovastatin was docked with various proteins using 
Table 1. Yield of lovastatin using various solid substrates

\begin{tabular}{lcc}
\hline Solid substrates & Inhibition zone $(\mathbf{m m})$ & Concentration of lovastatin $(\boldsymbol{\mu g} / \mathbf{m l})$ \\
\hline Wheat bran & 7 & 115 \\
Rice straw & 2.4 & 39.5 \\
Rice bran & 3.1 & 51 \\
Sugarcane bagasse & 1.9 & 31.1 \\
\hline
\end{tabular}

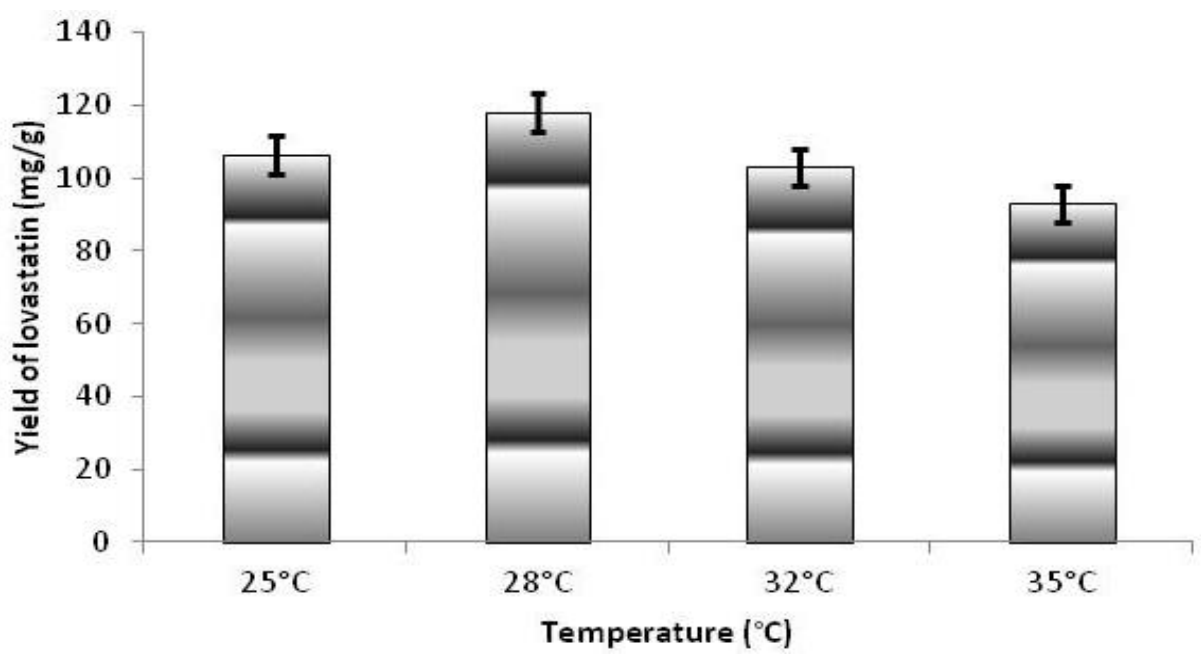

Figure 1. Effect of temperature on lovastatin production on wheat bran as a substrate.

Table 2. Active sites of proteins related to Alzhemier's disease.

\begin{tabular}{cllcc}
\hline S/N & Protein & PDB ID & Binding affinity & Binding sites \\
\hline 1 & Tau Protein & 1J1B & -8.1 & Asn 564 \\
& & & & Pro 636 \\
& & & & Arg 641 \\
& & 2AZ5 & -7.9 & Tyr 634 \\
2 & TNF- $\alpha$ & & & Tyr 552 \\
& & TNF- $\beta$ & -7.6 & Gly 382 \\
3 & & & & Oxygen \\
\hline
\end{tabular}

autodock vina to study its medicinal properties, site of action and its mechanism of binding over proteins for the treatment of various disorders.

\section{Proteins responsible for Alzheimer's disease}

Alzheimer's is a disease where the brain loses its functions (memory and thinking), as time progress, it leads to death. Various proteins like tumor necrosis factor (TNF), Tau proteins are responsible for the cause of the disease (Gong et al, 2010). Lovastatin has shown some effects on Alzheimer's disease; a study was carried out to find the interaction between various proteins (Table 2) that are responsible for Alzheimer's disease and lovastatin.

\section{Proteins responsible for cancer proteins}

Cancer is the uncontrolled growth of cells; there are many cancers which are caused due to various reasons. Many proteins are responsible for the cause of cancer; an interaction study was done between various cancer protein and lovastatin drug molecule, to study the property of lovastatin on cancer cells (Xia et al., 2001). Total of five proteins were docked individually with lovastatin and their interaction and site of action on 
Table 3. Active region of cancer proteins.

\begin{tabular}{|c|c|c|c|c|}
\hline $\mathrm{S} / \mathrm{N}$ & Protein & PDB ID & Binding affinity & Binding sites \\
\hline 1 & Glycogen synthase kinase $-3 \beta$ & 1UV5 & -8.1 & $\begin{array}{c}\text { Lys } 85 \\
\text { Arg } 141\end{array}$ \\
\hline 2 & Thymidylate Synthase & $1 \mathrm{JU} 6$ & -7.7 & $\begin{array}{l}\text { Met } 881 \\
\text { Arg } 650\end{array}$ \\
\hline 3 & TGF-beta receptor type I & $1 \mathrm{PY} 5$ & -9.5 & $\begin{array}{l}\text { Lys } 213 \\
\text { Ser } 287\end{array}$ \\
\hline 4 & Focal adhesion kinase 1 & $3 B Z 3$ & -7.1 & $\begin{array}{l}\text { Thr } 474 \\
\text { Arg } 569\end{array}$ \\
\hline 5 & Dihydrofolate reductase & $3 \mathrm{Gl} 2$ & -6.7 & $\begin{array}{c}\text { Ser } 118 \\
\text { Thr } 56 \\
\end{array}$ \\
\hline
\end{tabular}

Table 4. Active sites of apoptosis protein.

\begin{tabular}{|c|c|c|c|c|}
\hline $\mathrm{S} / \mathrm{N}$ & Protein & PDB ID & Binding Affinity & Binding sites \\
\hline \multirow[t]{3}{*}{1} & Caspase-3 & 1GFW & -7.7 & Ser 209 \\
\hline & & & & Ser 65 \\
\hline & & & & Arg 207 \\
\hline \multirow[t]{2}{*}{2} & Cyclin-dependent protein kinase-7 & 1UA2 & -7.6 & Leu 257 \\
\hline & & & & His 258 \\
\hline \multirow[t]{2}{*}{3} & Cyclin-dependent protein kinase- 5 & $1 \mathrm{UNH}$ & -8.2 & Asn 408 \\
\hline & & & & Asn 421 \\
\hline \multirow[t]{2}{*}{4} & Cyclin-dependent protein kinase-2 & $2 \mathrm{UZO}$ & -8.4 & His 42 \\
\hline & & & & Gly 122 \\
\hline \multirow[t]{2}{*}{5} & Cyclin-dependent protein kinase-9 & 3BLR & -8.7 & Glu 107 \\
\hline & & & & Asp 109 \\
\hline
\end{tabular}

proteins (Table 3) were studied.

\section{Proteins responsible for apoptosis}

Apoptosis is a process of programmed cell death, which occurs in multi-cellular organism. The process helps in regulation of cell cycle, repair of cell damage and also mitochondrial regulation. Malfunction of apoptosis may lead to several problems depending on its property, where insufficient apoptosis may lead to cancer, auto immune disorder and several viral infections, while excessive apoptosis may leads to several neurodegenerative problems and also cause myocardial infarction. Lovastatin shows inhibition over apoptosis (Tandon et al., 2005), so a docking was carried out for six apoptosis protein against lovastatin as a ligand (Table 4), to study the efficiency of lovastatin for the treatment of various diseases.

\section{DISCUSSION}

A maximum yield of $115 \mu \mathrm{g} / \mathrm{ml}$ of lovastatin was obtained when wheat bran was used as a solid substrate. Followed by rice bran, rice straw, sugarcane bagasse gave a yield of $51,39.5$ and $31.5 \mu \mathrm{g} / \mathrm{ml}$, respectively. The maximum yield of lovastatin was obtained from wheat bran, which may be due to easy absorption of nutrients from them and also due to maintenance of moisture content in the substrate. The temperature optimization which increases the yield at an optimum condition of $28^{\circ} \mathrm{C}$ is in accordance with the results obtained by Shami et al. (2007). A considerable yield of 106.5 and $103 \mathrm{mg} / \mathrm{g}$ lovastatin was obtained at temperature 25 and $32^{\circ} \mathrm{C}$, respectively. A low yield of lovastatin was obtained at other temperatures ( 35 and $40^{\circ} \mathrm{C}$ ). This may be due to the incompatibility of the organism to grow at these temperatures and also due to raise in temperature, there is a great loss in the moisture content which affects the growth of the organism which in turn reduced the yield of lovastatin.

\section{Inhibition of lovastatin with HMG-Co A reductase (PDB ID: 1DQ9)}

A docking study was carried out to study the effect of 


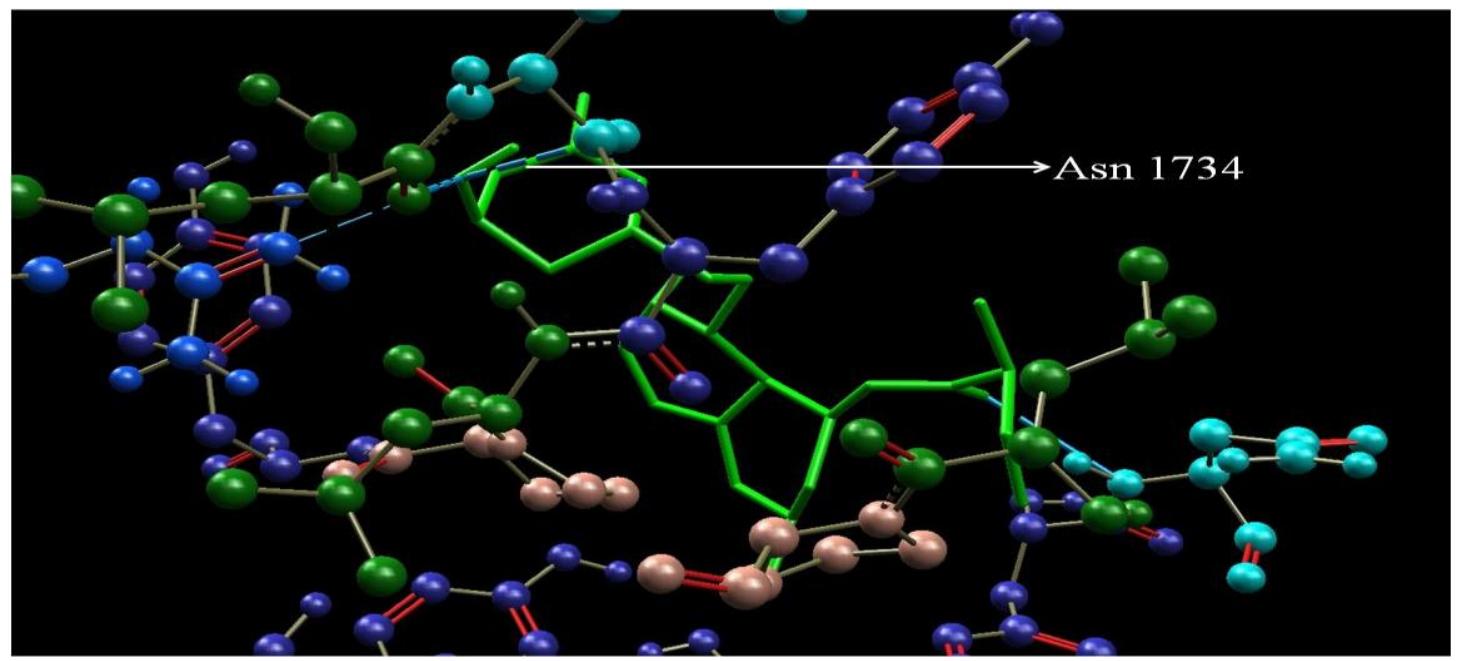

Figure 2. Binding of proteins exhibiting the inhibition of HMG Co A reductase.

lovastatin on inhibition of HMG-Co A reductase enzyme (Figure 2) in order to reduce the blood cholesterol level. Docking studies showed that lovastatin was bound to the active region of reductase enzyme (PDB ID: 1DQ9) (Istvan et al., 2000), thereby inhibiting them. A hydrogen bond interaction was made with Asn amino acid residue at 1734 position with the oxygen atom in the ligand, the length between the oxygen and Asn at 1734 position is 3.0633 and the energy utilized for the interaction is $2.5 \mathrm{kcal} / \mathrm{mol}$. Another hydrogen bond interaction was made in ligand with the protein; the interaction was between the oxygen in the lactone ring and to the Leu and Arg amino acid residue at 1319 and 1306 positions, respectively in the protein. The energy utilized for the interaction of ligand with Leu $1319(-2.4273 \mathrm{kcal} / \mathrm{mol})$ is much higher than with Arg $1306(-0.7036 \mathrm{kcal} / \mathrm{mol})$. Thus, three interactions occur between lovastatin and the protein, where the interaction between Asn and Leu were more effective. The overall binding energy between the ligand and the HMG Co $A$ is $-11.2 \mathrm{kcal} / \mathrm{mol}$. This proves that the interaction occurs between lovastatin and HMG Co $A$ reductase, was more effective and helps in the reduction of cholesterol levels in blood by inhibiting the HMG Co A reductase enzyme (PDB ID: 1DQ9).

\section{Alzheimer's disease}

\section{Interaction between lovastatin and Tau protein (PDB ID: 1J1B)}

Tau proteins are the macromolecules which play a vital role in regulation of microtubules in brain and central nervous system (CNS). Malfunction of Tau protein leads to dementia such as Alzheimer's disease. This can be regulated by binding various drugs with Tau protein (PDB ID: 1J1B). Lovastatin was docked with Tau protein
(Figure 3), to know the effectiveness of the drug to cure Alzheimer disease. Docking of lovastatin with Tau protein showed (Figure 3) a hydrophilic interaction at the lactone ring of lovastatin with Pro 636, Arg 641 and Tyr 634; the binding energy was $-2.5,-2.0$ and $-2.5 \mathrm{kcal} / \mathrm{mol}$, respectively, and the length of the hydrogen bond between ligand and Pro 636, Arg 641, Tyr 634 are 2.77, $3.19,3.05$, respectively. From this, it is clear that the chance of interaction will be high with Tyr 634 position than with Arg and Tyr at position 641 and 634. Another interaction occurs at the free oxygen end of the ligand with Tau protein at 564 position of Asn amino acid, the binding energy is $-0.29 \mathrm{kcal} / \mathrm{mol}$ and the length between them is 3.416. Thus the interaction is effective with Tyr at position 634 and Asn at 564 position, which shows that lovastatin binds with Tau protein, but its effectiveness of the interaction is not well known since the inhibition may affect the formation of microtubules and its stabilization.

\section{Interaction between lovastatin and TNF a protein (PDB ID: 2AZ5)}

TNF- $\alpha$ protein belongs to cytokine group, where it plays a role in systemic regulation of inflammation. The dysfunction of TNF- $\alpha$ may leads to various disease like Alzheimer's, cancer, inflammation bowel disorders. Many drugs were designed to target particular sites of TNF- $\alpha$ protein at the particular sites for the regulation of the protein and to reduce the diseases. Docking was carried out with lovastatin and TNF- $\alpha$ protein (PDB ID: 2AZ5) are shown in Figure 4, to treat Alzheimer's disease. Docking results showed two hydrogen bond interaction with lovastatin, where a single interaction occurs with the oxygen atom present in lactone ring of lovastatin to Tyr 552 and with the Gly 382 aminoacid residues of TNF a protein, the binding energy between Tyr and ligand at 


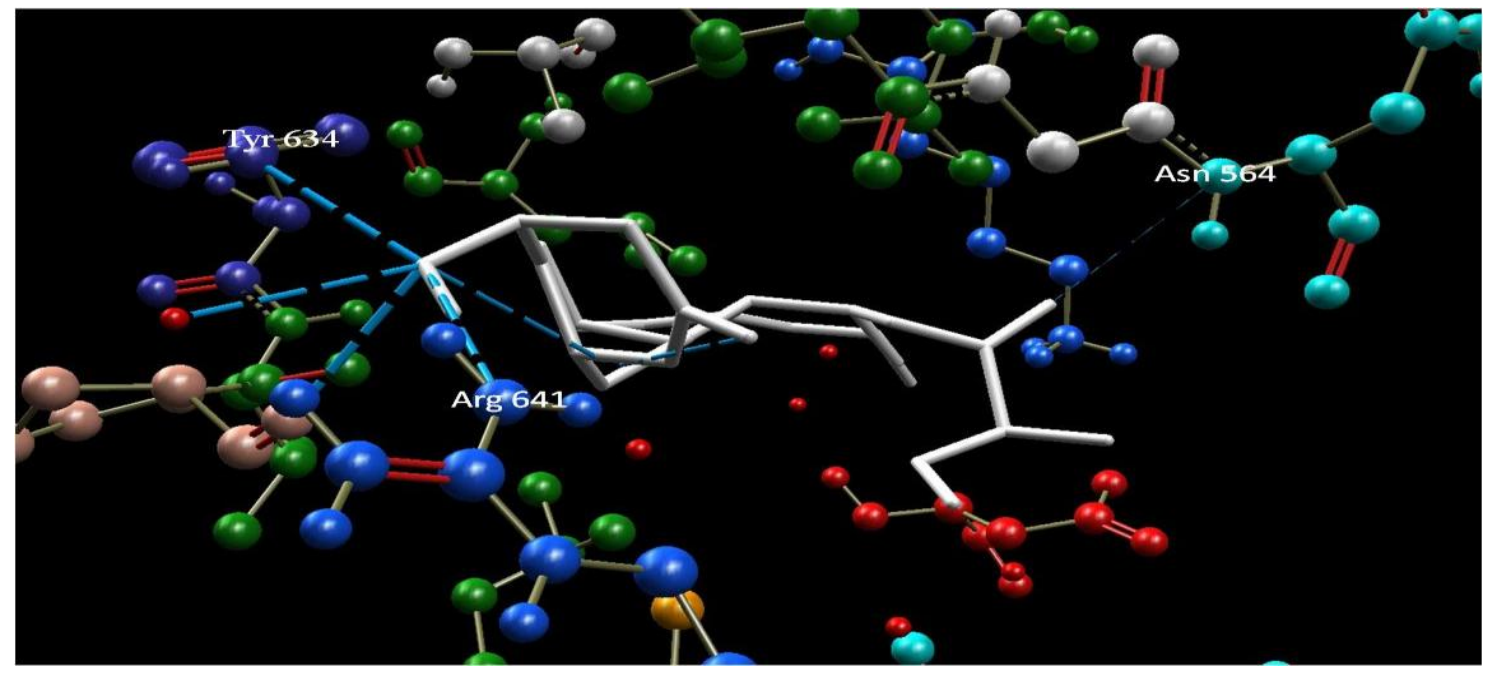

Figure 3. Binding of Lovastatin and Tau protein.

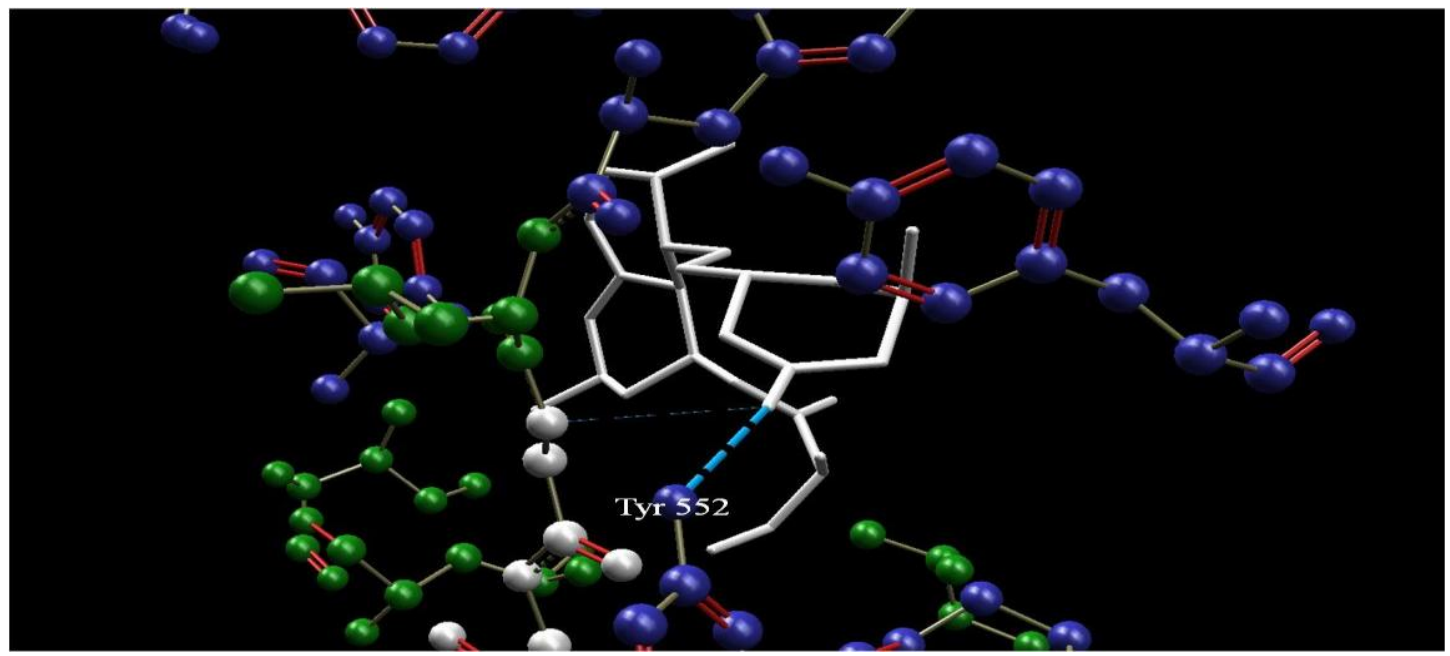

Figure 4. Binding of Lovastatin and TNF $\alpha$.

position 552 is $-2.5 \mathrm{kcal} / \mathrm{mol}$ and the length between them is 2.70. Another interaction occurs at the same position of the ligand molecule with Gly at position 382 and the hydrogen bond interaction is $-0.2 \mathrm{kcal} / \mathrm{mol}$. Thus the interaction will be maximum only with Tyr molecule than with Gly since the energy used and the interaction between them is stronger. The overall energy utilized for the hydrogen bond interaction is $-7.9 \mathrm{kcal} / \mathrm{mol}$, which is slightly higher than the interaction with Tau protein. Thus lovastatin may reduce Alzheimer's disease in humans by inhibiting TNF a protein at the specific sites.

\section{Interaction between Lovastatin and TNF $\beta$ protein (PDB ID: 1TNR)}

TNF- $\beta$ is a similar kind of protein as TNF- $\alpha$, where it shows $30 \%$ homologues to one another. The interaction of lovastatin with TNF- $\beta$ protein (1TNR) was not that efficient (Figure 5), only one hydrogen bond interaction took place at the lactone ring position with the oxygen molecule and also the energy utilized for the overall interaction is $-7.6 \mathrm{kcal} / \mathrm{mol}$, which is much higher compared with the interaction of other proteins with lovastatin. The hydrogen bond interaction was weak and the chance of interaction is very much limited than compared with the other proteins such as Tau, TNF- $\alpha$.

\section{Effect of lovastatin on Alzheimer's disease}

Docking studies were done with various proteins responsible for Alzheimer's disease with lovastain. In this, a maximum interaction was made with Tau protein (1J1B) 


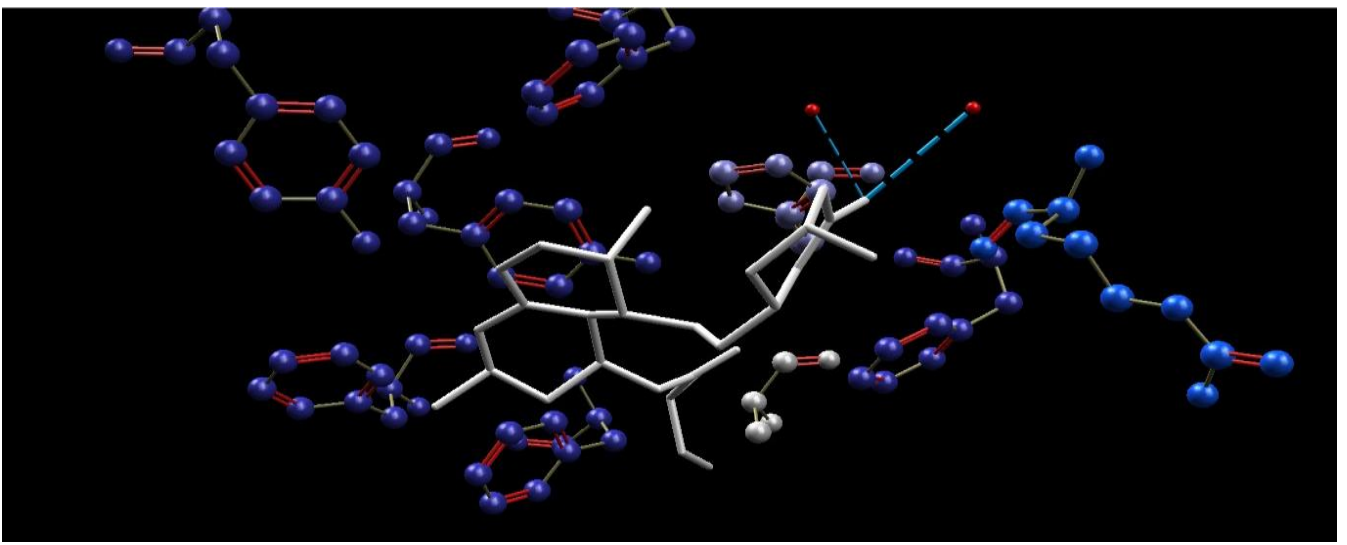

Figure 5. Binding of lovastatin and TNF $\beta$.

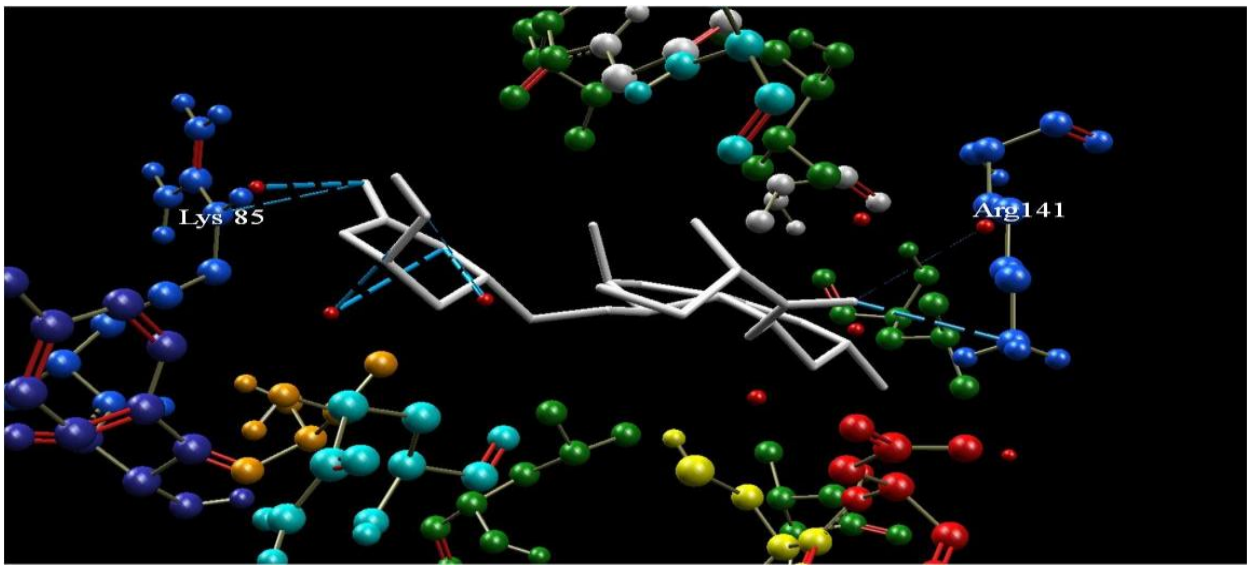

Figure 6. Binding of lovastatin and glycogen synthase kinase-3ß.

than with other two proteins, but the interaction occurs at the same region in the lovastatin molecule. TNF- $\alpha$ had only two interactions with lovastatin and the energy used was also minimum, the interactions was very effective than with other two proteins. So the drug may interact more effectively with TNF- $\alpha$ protein than with Tau, TNF- $\beta$ proteins. Thus the drug may help in curing Alzheimer's disease by interaction with TNF- $\alpha$ protein with the specific amino acids at particular sites.

\section{Cancer proteins}

\section{Interaction between lovastatin and glycogen synthase kinase-3 $\beta$ (PDB id: 1UV5)}

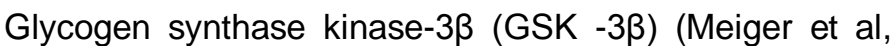
2003) mediates the addition of phosphate molecules to serine and threonine residues. GSK $-3 \beta$ phosphorylates at the active sites of serine, threonine residues. The active sites of GSK- $3 \beta$ are present at 181, 200, 97 and 85 positions. GSK-3 $\beta$ has a role in apoptosis and also studies showed that it has a role in cancer formation (Luo, 2009.). Certain cancer can be treated by inhibition of GSK-3 $\beta$, lovastatin has been shown to inhibit GSK-3 $\beta$ at active sites (Figure 6). The docking studies showed that lovastatin binds to GSK- $3 \beta$ at different sites with a binding affinity of $-8.1 \mathrm{kcal} / \mathrm{mol}$. Lovastatin binds to Lys residue at 85 position, which is one of the active site present in GSK-3ß. The hydrogen bond interaction utilizes the energy of $-2.10 \mathrm{kcal} / \mathrm{mol}$ and the bond length of 3.17 at $85^{\text {th }}$ position. Another interaction occurs at the oxygen of the lactone ring with Arg aminoacid residue at $141^{\text {th }}$ position. The site where it binds is not an active site, so the interaction may not have any influence over the inhibition of GSK- $3 \beta$. Thus lovastatin may act as an anticancer drug by inhibiting GSK-3 $\beta$ at position 85 and 141 , where the interactions occur more effectively and also, they are the active sites present in GSK- $3 \beta$ proteins

\section{Interaction between lovastatin and thymidylate synthase (PDB id: 1JU6)}

Thymidylate synthase is a key in formation of thymidine 


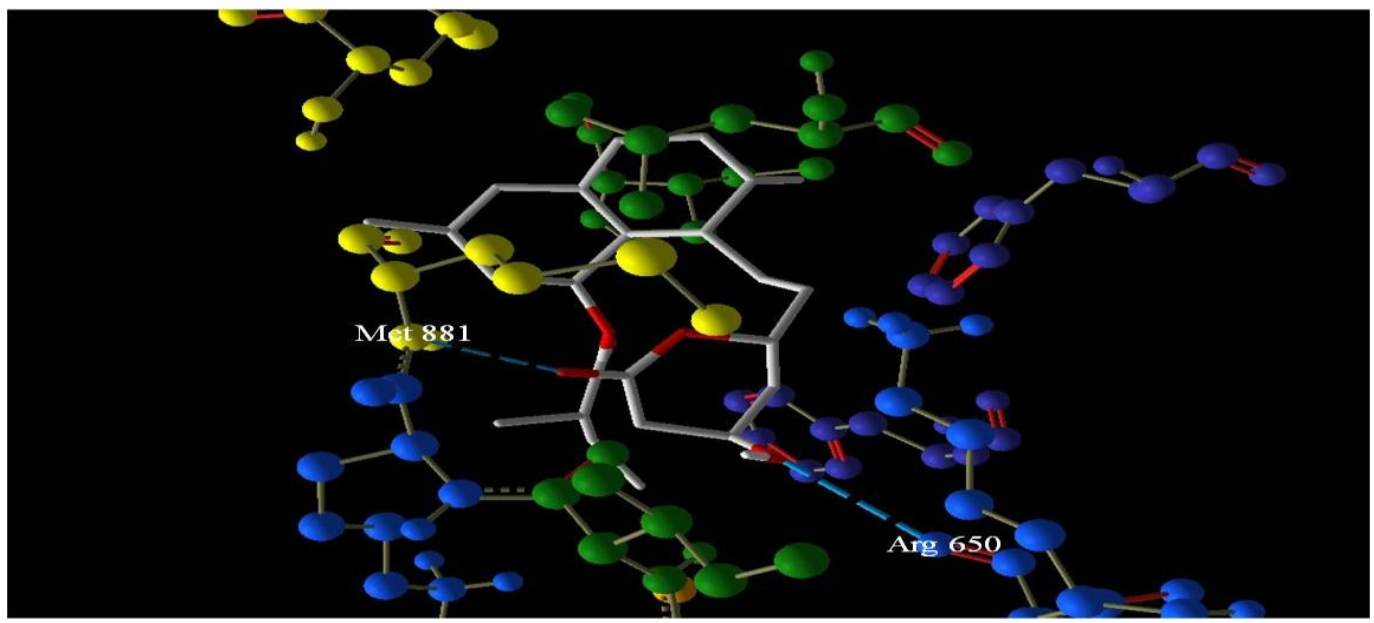

Figure 7. Binding of lovastatin and thymidylate synthase.

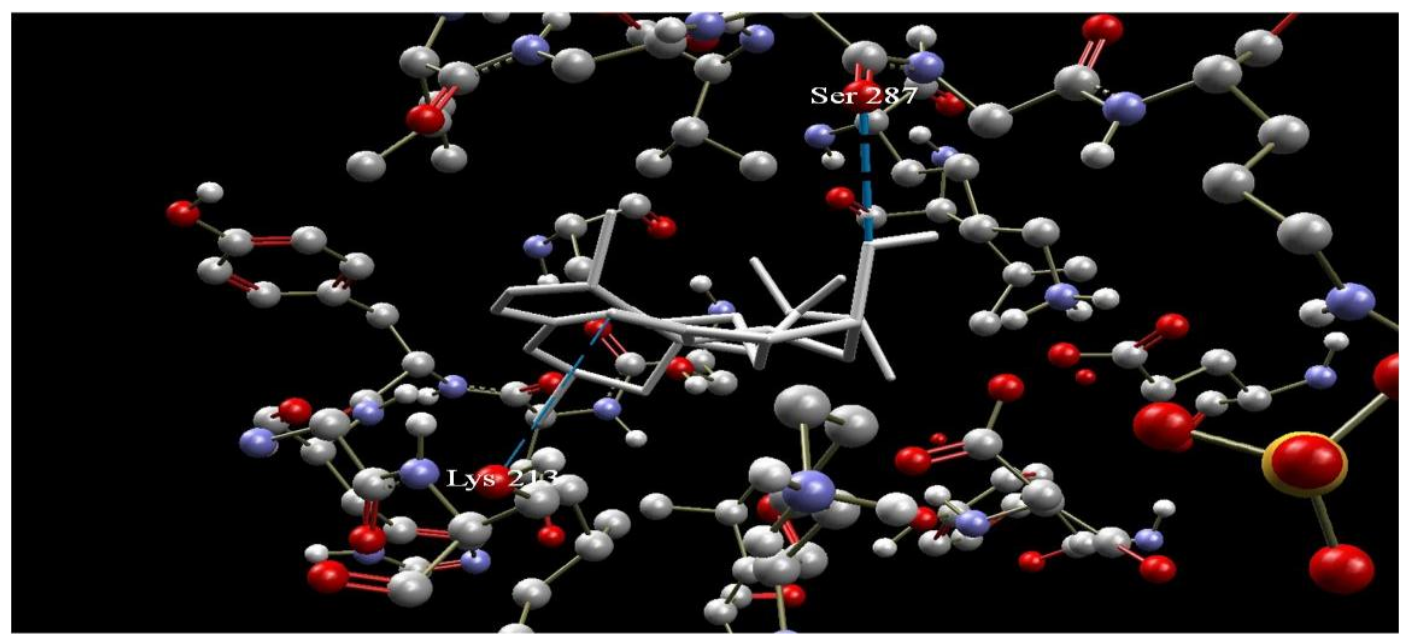

Figure 8. Binding of lovastatin and TGF- $\beta$ receptor type I.

monophosphatae, which in turn is used in the synthesis and repair of DNA (Sayre et al., 2001). They also play a significant role in liver cancer proliferation, where thymidylate synthase was induced by Late SV40 (LSF). The inhibiton of this protein may stop the cancer induction in liver cells of humans. Docking study of lovastatin with thymidylate synthase showed an interaction between them (Figure 7).

Lovastatin binds thymidylate synthase at 881 and 650 positions with Met and Arg residues. Where a hydrogen bond interaction takes place with the oxygen atoms in the lactone rings, the hydrogen bond interaction between the aminoacid and ligand used a energy of $-7.7 \mathrm{kcal} / \mathrm{mol}$. The energy utilized was high since the binding regions are not an active site and also the hydrogen interaction was a weaker one at that particular site. From the docking studies, it is clear that the chance of interaction between lovastatin and thymidylate synthase is weak. This study proves that the ligand may not bind with thymidylate synthase for the treatment of cancer in human.

\section{Interaction between lovastatin and TGF- $\beta$ receptor type I (PDB id: 1PY5)}

TGF- $\beta$ receptor (PDB id: 1PY5) is found in the tissue types including brain, kidney, liver and testes. They also play a key role in proliferation and differentiation of many cell types. A change in protein may induce cancer in human cell. By inhibition of these cells, it may help in the regulation of cancer in human cells. Lovastatin was docked with TGF- $\beta$ receptor protein (Figure 8 ), to find its effectiveness in inhibition for the treatment of cancer.

A binding occurs in protein at position 213 and 287, with lovastatin ligand on the lactone ring sites. The hydrogen interaction is higher and also elctrostatic interactions were found between them. The hydrogen bond formation between the ligand and the protein used energy of $-9.5 \mathrm{kcal} / \mathrm{mol}$, where the ligand binds to Lys and Ser residues of the protein. The interaction was stronger between them and so the inhibition of TGF- $\beta$ receptor may occur effectively by binding of lovastatin at 


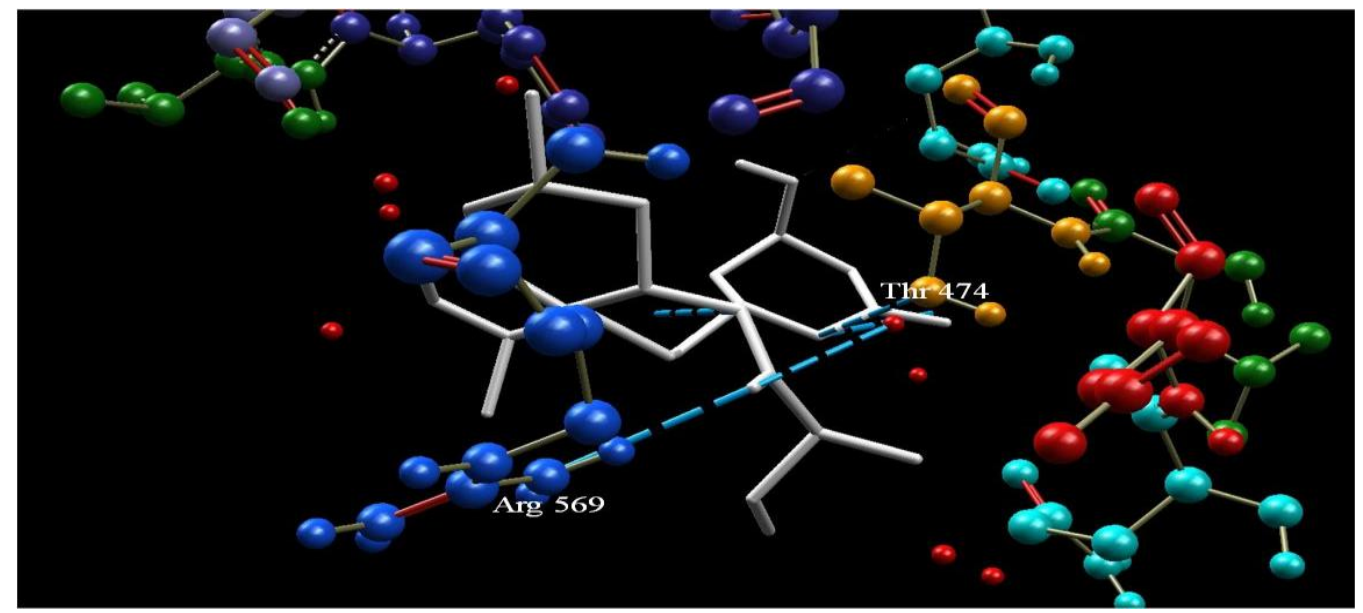

Figure 9. Binding of lovastatin and focal adhesion kinase 1.

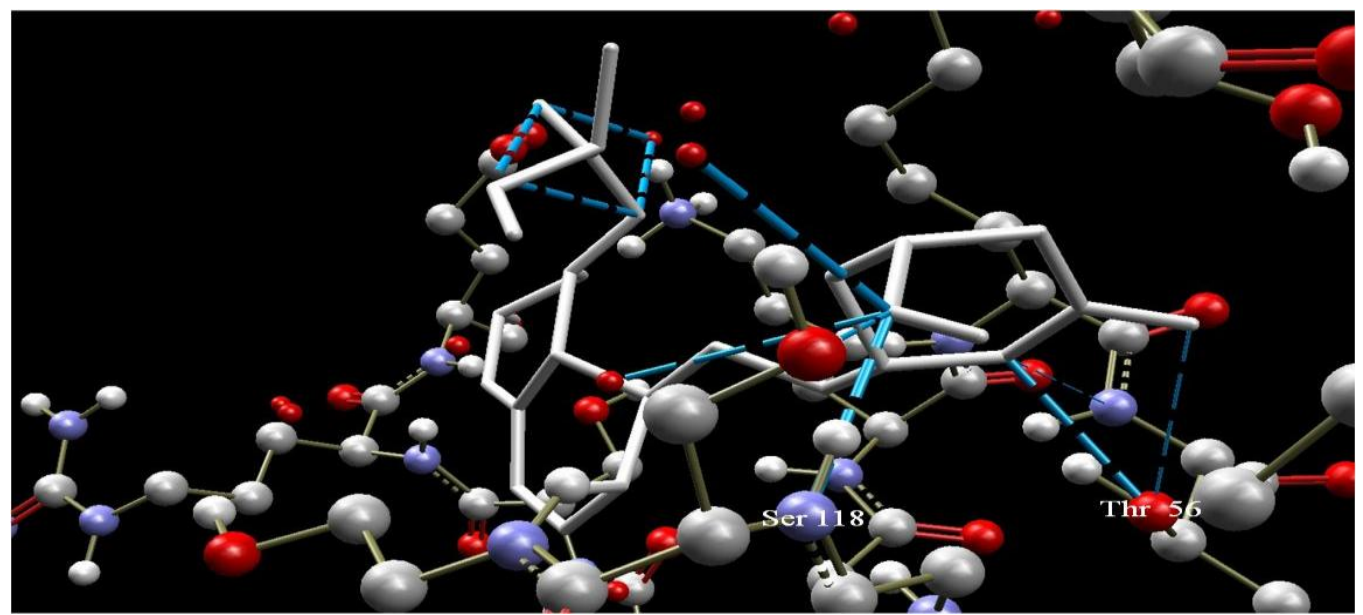

Figure 10. Binding of lovastatin and dihydrofolate reductase.

the targeted sites and thereby reducing the cancer effects in human.

\section{Interaction between lovastatin and focal adhesion kinase 1 (PDB id: 3BZ3)}

Focal adhesion kinase 1 (FDK-1) (PDB id: 3BZ3) is a non receptor protein that plays a vital role in cell adhesion, migration and cell proliferation. They also play a very vital role in cell apoptosis. An increase in FDK-1 may lead to cancer in the cells, which may be due to cell adhesion and proliferation nature of FDK-1. By inhibiting FDK-1 with lovastatin, it may regulate cancer in human. Lovastatin showed a mild interaction with FDK-1 protein (Figure 9), when interacted at 464 and 569 positions. The energy utilized for the hydrogen bond interaction at Arg and $\mathrm{Thr}$ residues is $-7.1 \mathrm{kcal} / \mathrm{mol}$. More energy was utilized during the hydrogen bond interaction, which may be due to the other interaction which occurred with the hydrogen molecules present in the FDK-1 protein. Further studies are required to study the effectiveness of lovastatin with FDK-1 proteins, for future use as an anticancer drug.

\section{Interaction between lovastatin and dihydrofolate reductase (PDB id: 3GI2)}

Dihydrofolate reductase (PDB id: $3 \mathrm{GI}$ ) is an enzyme that helps in the reduction of tetrahydrofolic acid to dihydro folic acid. Many drugs are designed targeting dihydrofolate reductase enzyme, since it plays a role in proliferation of cancer cells. Docking studies showed that lovastatin also targets dihydrofolate reductase enzyme (Figure 10) at a specific site with an energy utilization of 6.7. Lovastatin binds at 118 and 56 positions, with Ser and Thr residues, at hydrogen bond length of 3.34 and 


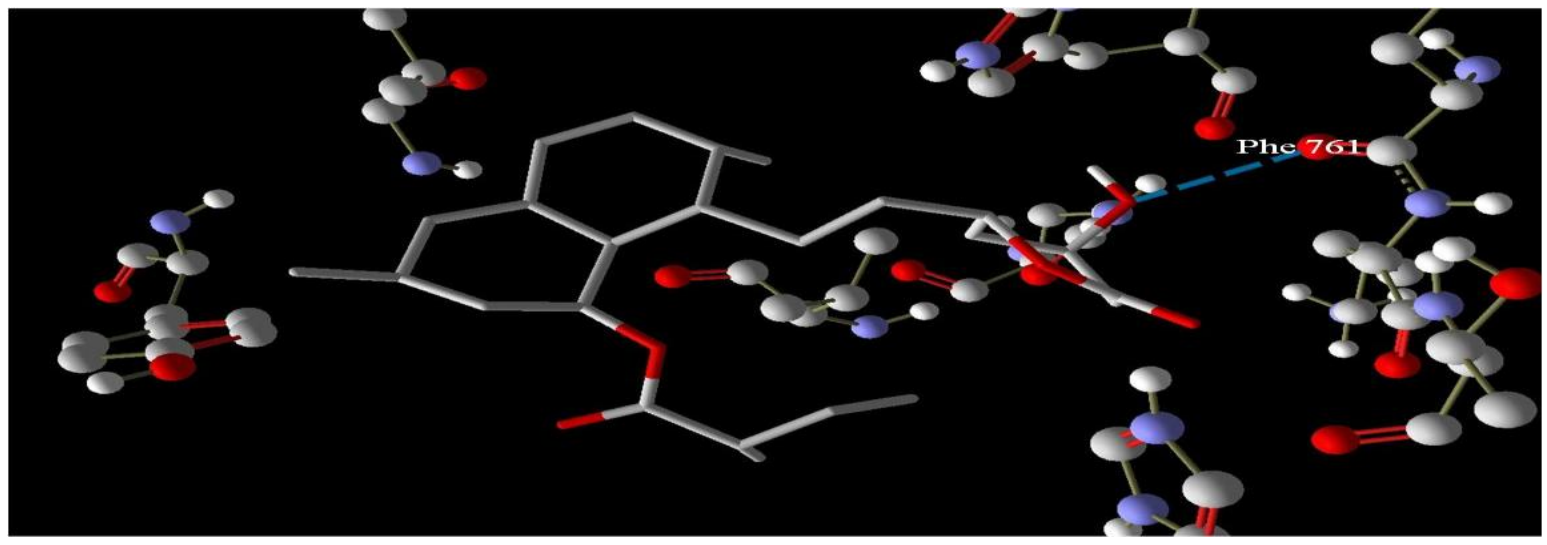

Figure 11. Binding of lovastatin and cyclooxygenase.

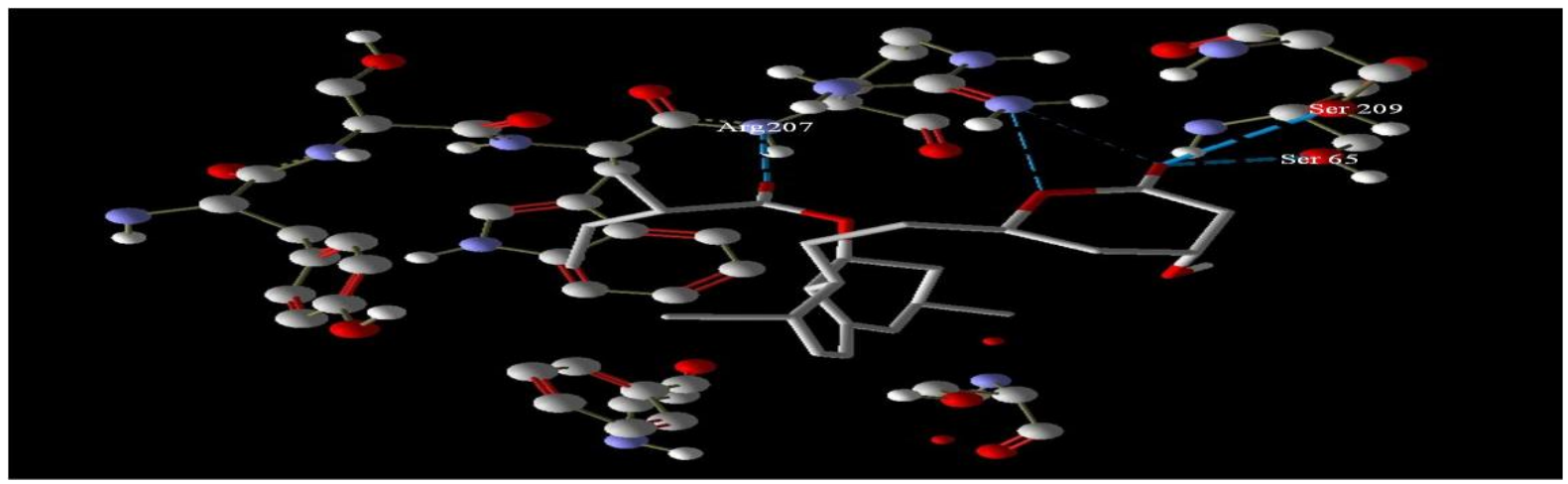

Figure 12. Binding of lovastatin and caspase-3.

2.87. Energy utilized for the bond formation is -1.26 and $2.5 \mathrm{kcal} / \mathrm{mol}$, respectively. The binding of lovastatin with protein utilizes more energy and the bond may have an interaction with other hydrogen molecules present in the enzymes. Thus lovastatin may inhibit the cancer protein by inhibiting dihydrofolate reductase enzyme, by which lovastatin can be used in the treatment of cancer.

\section{Inhibition of cyclooxygenase using lovastatin (PDB: 1CX2)}

Cyclooxygenase (COX) is an important enzyme in formation of prostaglandins. COX plays a vital role in inflammation and so many drugs were designed to inhibit the enzyme. In our study, lovastatin's anti-inflammatory property was checked using Autodock Vina with COX (PDB: 1CX2). The docking showed a binding of lovastatin with COX protein at a single site (Figure 11), 761 positions with Phe residue. A single hydrogen bond interaction with the protein was not efficient when docking was made with other proteins. The study shows that the lovastatin may not be much efficient for the treatment of anti-inflammatory drugs.

\section{Apoptosis}

\section{Docking of lovastatin with Caspase-3 (PDB ID: 1GFW)}

Caspase is an essential protein in apoptosis. Dysfunction of caspase protein may lead to tumor and inhibition of caspase-3 (PDB ID: 1GFW) which helps in treating tumor in humans (Lee et al., 2000). In our study, lovastatin was docked with caspase protein to check its efficiency in treatment of tumor in humans (Figure 12). The study reveals that lovastatin binds at 65,209 and 207 positions, with Ser and Arg residues. The binding energy utilized was $-7.7 \mathrm{kcal} / \mathrm{mol}$, which was very high for the binding of lovastatin with caspase enzyme. Thus the studies reveal that, lovastatin binds with caspase protein but not efficient enough for the treatment of cancer in humans, by interacting with caspase- 3 .

\section{Docking of lovastatin with cyclin-dependent protein kinase-7 (PDB ID: 1UA2)}

Cyclin-dependent protein kinase-7 (CDK-7) binds with lovastatin at two sites, 257 and 258 positions, with Leu and $\mathrm{His}$ residues (Figure 13). The energy utilized for 


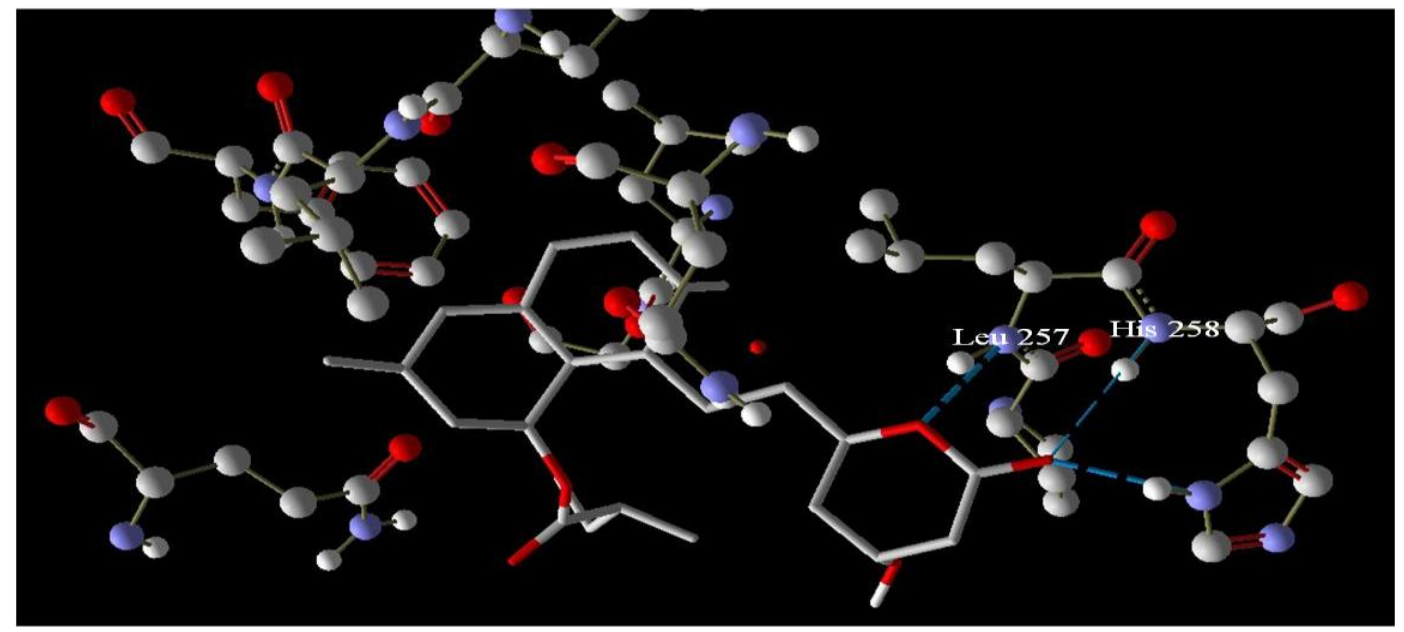

Figure 13. Binding of lovastatin and cyclin-dependent protein kinase-7.

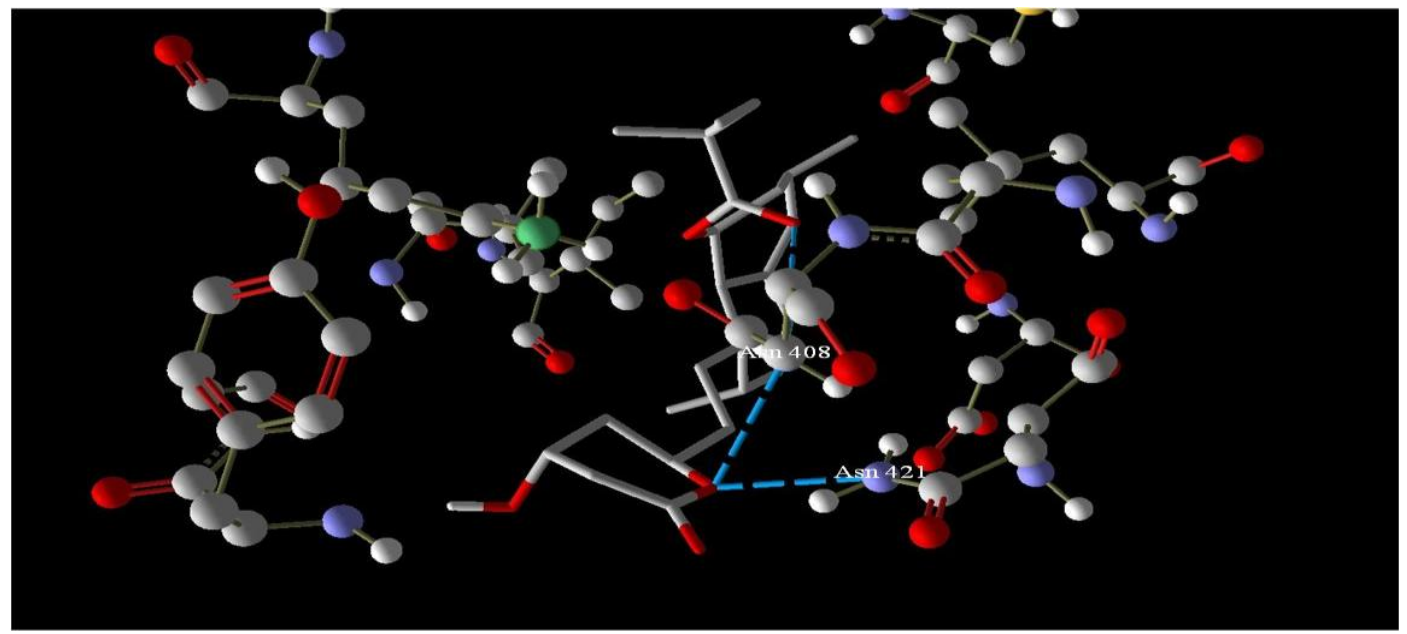

Figure 14. Binding of lovastatin and cyclin-dependent protein kinase-5.

hydrogen bond interaction is $-7.6 \mathrm{kcal} / \mathrm{mol}$, where the bond length is 2.83 and 2.57 and the energy used for each interaction is -2.5 and $-2.1 \mathrm{kcal} / \mathrm{mol}$, with Leu and His residues, respectively. The hydrogen bond interaction of lovastatin was not efficient enough to inhibit CDK-7 and also the energy utilized is much higher for the interactions to occur. Thus the mechanism of inhibiting CDK-7 is not an efficient method for the treatment of cancer using lovastatin.

Cyclin-dependent protein kinase-5 (CDK-5) is a similar kind of protein as CDK-7, which has similar properties in regulation of cells. The CDK- 5 was docked with lovastatin molecules (Figure 14), where it binds to Asn amino acid residues at position 408 and 421 . The energy utilized for the hydrogen bond interaction is $-8.2 \mathrm{kcal} / \mathrm{mol}$, where the energy utilized for binding at the active site is more when compared with docking studies obtained from other cancer proteins. The results show that the chances of lovastatin acting over CDK-5 is much less compared with other proteins for the treatment of cancer cell.

\section{Docking of lovastatin with cyclin-dependent protein kinase-2 (PDB ID: 2UZO)}

Cyclin-dependent protein kinase-2 (CDK-2) also plays a vital role in regulation of cell cycle, apoptosis. Docking of lovastatin showed two hydrogen bond interactions with CDK-2 at 42 and 122 positions with His and Gly residues (Figure 15). The hydrogen bond interaction utilized a binding energy of $-8.2 \mathrm{kcal} / \mathrm{mol}$, which is very high for the interaction with apoptosis proteins. Thus the inhibition of CDK-2 will also be less efficient for the interaction with lovastatin drug. Since the energy utilized is much higher 


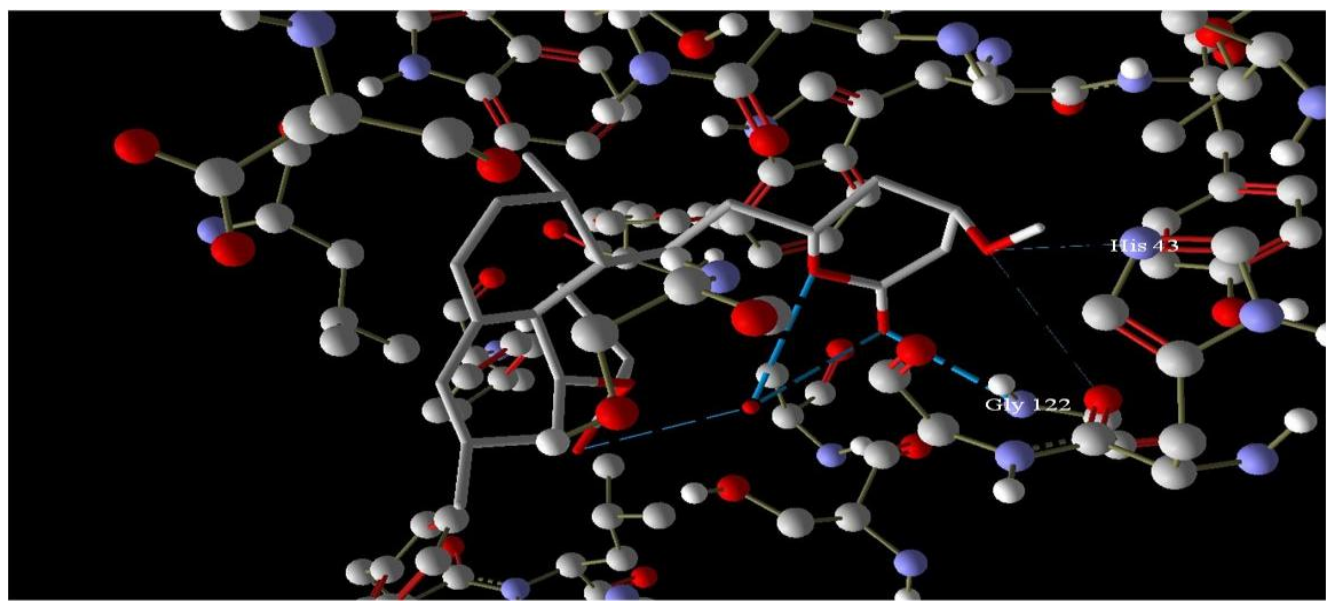

Figure 15. Binding of lovastatin and cyclin-dependent protein kinase-2.

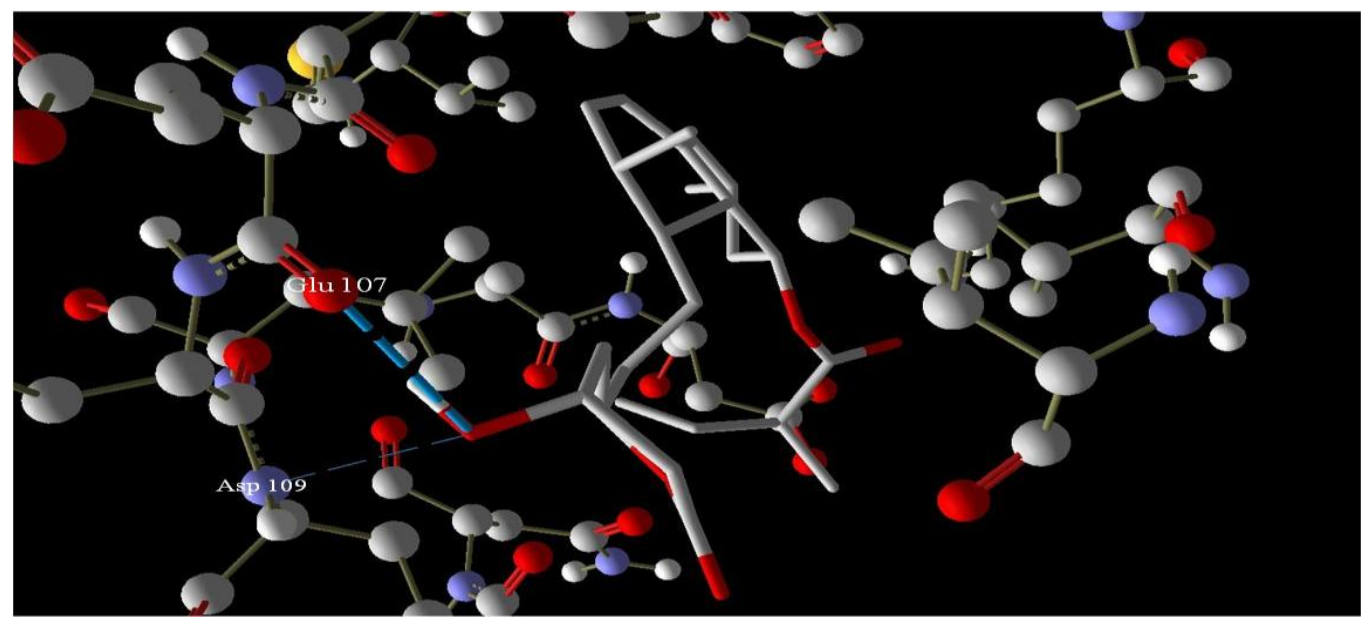

Figure 16. Binding of lovastatin and cyclin-dependent protein kinase-9.

for the interaction, the drug may bind with protein molecules other than CDK-2 proteins.

\section{Docking of lovastatin with cyclin-dependent protein kinase-9 (PDB ID: 3BLR)}

Docking of lovastatin with cyclin-dependent protein kinase-9 (CDK-9) was carried out, the results obtained showed the binding sites of lovastatin with CDK-9 at 107 and 109 positions. The hydrogen binding interaction utilized $-8.7 \mathrm{kcal} / \mathrm{mol}$ of energy, where the binding occurred only at one site in the lovastatin drug as shown in Figure 16. This interaction was not that efficient since two hydrogen bond interaction occurs at same place in the lovastatin drug. Thus lovastatin's mechanism of action over cancer may not be induced by inhibiting CDK9 proteins, since this interaction consumes more energy and also the hydrogen bond interaction was not that efficient in inhibition of CDK-9 proteins.

\section{Conclusion}

The docking studies reveal that lovastatin has various properties like anti-lipidemic, anti-cancer and Alzheimer's disease. The mechanism of lovastatin drug as antilipidemic, occurs by inhibiting HMG-Co A enzyme, which is a precursor in cholesterol synthesis. Similarly, lovastatin can help in curing alzheimer's disease, by inhibiting the Tau protein than other proteins like TNF- $\alpha$ and TNF- $\beta$. The docking study was extended to check the anti-cancer property of lovastatin, where ten proteins were docked and results showed that the inhibition of cancer cell by lovastatin was efficient by inhibiting TGF $\beta$ receptor protein.

\section{ABBREVIATIONS}

PDA, Potato dextrose agar; TNF, tumor necrosis factor; CNS, central nervous system; GSK $-3 \beta$, glycogen synthase kinase-3ß; COX, cyclooxygenase. 


\section{REFERENCES}

Barakat BB, Muahmmad I, Niaz A, Naveed M, Rehmanullah (2013). Antispasmodic potential of leaves, barks and fruits of Zanthoxylum armatum DC. Afr. J. Pharm. Pharmacol. 7(13):685-693.

Danuri H (2008). Optimizing Angkak Pigments and Lovastatin Production by Monascus purpureus. HAYATI J. Biosci. 15(2):61-66.

Eckert GP, Wood WG, Muller WE (2005). Statins: drugs for Alzheimer's disease? J. Neural Transm. 112(8):1057-1071.

Endo A, Kuroda M, Tsujita Y (1976) ML-236A, ML-236B, and ML-236C, new inhibitors of cholesterogenesis produced by Penicillium citrinium, J. Antibiot. 29(12):1346-1348.

Endo A (1992). The discovery and development of HMG-CoA reductase inhibitors. J. Lipid Res. 33: 1569-1582.

Gong C-X, Grundke-lqbal I, Iqbal K (2010). Targeting Tau Protein in Alzheimer's Disease. Drugs Aging. 27(5):351-365.

Istvan ES, Palnitkar M, Buchanan SK, Deisenhofer J (2000). Crystal structure of the catalytic portion of human HMG-CoA reductase: insights into regulation of activity and catalysis. EMBO J. 19: 819 830.

Kumar MS, Kumar PM, Sarnaik HM, Sadhukhan AK (2000). A rapid technique for screening of lovastatin-producing strains of Aspergillus terreus by agar plug and Neurospora crassa bioassay. J. Microbiol. Meth. 40:99-104.

Lee D, Long SA, Adams JL, Chan G, Vaidya KS, Francis TA, Kikly K, Winkler JD, Sung CM (2000). Potent and selective nonpeptide inhibitors of caspases 3 and 7 inhibit apoptosis and maintain cell functionality. J. Biol. Chem. 276(21):16007-16014.

Luo J (2009). Glycogen synthase kinase 3b (GSK3b) in tumorigenesis and cancer chemotherapy. Cancer Lett. 273:194-200.

Meijer L, Skaltsounis AL, Magiatis P, Polychronopoulos P, Knockaert M, Leost M, Ryan (2003). GSK-3-Selective Inhibitors Derived from Tyrian Purple Indirubins. Chem. Biol. 10(12):1255-1266.

Rajput SJ, Raj HA (2009). Simultaneous Estimation of Ezetimibe and Lovastatin by Derivative Spectroscopy. Int. J. Chem. Tech. Res. 1(3):894-899.

Samiee SM, Moazami N, Haghighi S, Mohseni FA, Mirdamadi S, Bakhtiari MR (2003) Screening of lovastatin production by filamentous fungi. Iran Biomed. J. 7(1):29-33.
Samy AS, Mohamed HAA, Mona SM, Mona FW (2013). Antibacterial activities, chemical constitutes and acute toxicity of Egyptian Origanum majorana L., Peganum harmala L. and Salvia officinalis L. essential oils. Afr. J. Pharm. Pharmacol. 7(13):725-735.

Sayre PH, Moore JSF, Fritz TA, Biermann D, Gates SB, MacKellar WC, Pate VF, Strou RM (2001). Multi-targeted antifolates aimed at avoiding drug resistance form covalent closed inhibitory complexes with human and Escherichia coli thymidylate synthases. J. Mol. Biol. 313(4):813-829.

Srinu M, Phani GV, Moges F, Srilakshmi J, Sankar G, Prabhakar T, Lakshminarayana K (2010). Screening of HMG CO A Reductase inhibitor producing Marine Actinomycetes. JPRHC. 2(1):66-74.

Steenkamp V, Nkwane O, van Tonder J, Dinsmore A, Gulumian M (2013). Evaluation of the phenolic and flavonoid contents and radical scavenging activity of three southern African medicinal plants. Afr. J. Pharm. Pharmacol. 7(13):703-709.

Tandon V, Bano G, Khajuria V, Parihar A, Gupta S (2005). Pleiotropic effects of statins. Indian J. Pharmacol. 37(2):77-85.

Tobert JA (1987). New developments in lipid-lowering therapy: the role of inhibitors of hydroxymethylglutaryl-coenzyme A reductase. Circulation. 76:534-538

Trott O, Olson AJ (2010). AutoDock Vina: improving the speed and accuracy of docking with a new scoring function, efficient optimization and multithreading. J. Comput. Chem. 31:455-461.

Vilches Ferrón MA, Casas López JL, Sánchez Pérez JA, Fernández Sevilla JM, Chisti Y (2005). Rapid screening of Aspergillus terreus mutants for overproduction of lovastatin., World J. Microb. Biot. 21:123-125.

Xia Z, Tan MM, Wing WW, Dimitroulakos J, Minden MD, Penn LZ (2001). Blocking protein geranylgeranylazation is essential for lovastatin induced apoptosis of human acute myeloid leukemia cells. Leukem. 15:1398-1407. 